\title{
Physiological Responses of Wild and Cultivated Barley to the Interactive Effect of Salinity and Iron Deficiency
}

\author{
Sabeh Yousfi, Hayet Houmani, Fethia Zribi, Chedly Abdelly, and Mohamed Gharsalli \\ Laboratoire d'Adaptation des Plantes aux Stress Abiotiques (LAPSA), Centre de Biotechnologie de Borj-Cédria, P.O. Box 901, \\ 2050 Hammam-lif, Tunisia \\ Correspondence should be addressed to Sabeh Yousfi, yousfisabeh@yahoo.fr
}

Received 7 April 2012; Accepted 10 May 2012

Academic Editors: K. Okuno and L. Zeng

Copyright (๑) 2012 Sabeh Yousfi et al. This is an open access article distributed under the Creative Commons Attribution License, which permits unrestricted use, distribution, and reproduction in any medium, provided the original work is properly cited.

\begin{abstract}
Literature on the separate effects of salinity and inadequate Fe supply on plant growth and nutrient uptake, concentration, and distribution is abundant but little is known about the interactive effects of these two abiotic constraints. Here, we investigated the interactive effect of iron availability and salinity on physiological responses of cultivated and wild barley (Hordeum vulgare and H. maritimum resp.). Seedlings of both species were grown for 9 days, under complete nutrient solution with or without iron supply. Then, $\mathrm{NaCl}$ treatment was applied at different concentrations $(0,100,200$, and $300 \mathrm{mM})$ for 60 hours. After salt exposure, shoot water content of $H$. vulgare was significantly reduced as compared to $H$. maritimum. Furthermore, $\mathrm{Na}^{+}$accumulation in shoots increased parallel to increasing $\mathrm{NaCl}$ concentration in the medium. However, the increase was significantly higher in $H$. vulgare than in H. maritimum. These responses were associated with lower Fe absorption efficiency photosynthetic parameters in both species. The reduction was significantly higher in cultivated than in wild barley. Moreover, phytosiderophore exudation was enhanced in both species by direct (iron free medium) or indirect iron limitation (salt-induced iron limitation). Such a stimulation of phytosiderophore release was genotype and salt level dependant.
\end{abstract}

\section{Introduction}

It is well documented that hindrance effect of high soil alkalinity on plant growth is related to nutrients availability limitation; particularly of iron [1]. Under such tricky environmental conditions, higher plants induce special mechanisms for iron acquisition, involving a plasma membrane $\mathrm{H}^{+}$-ATPase to increase root proton release capacity and a plasma membrane $\mathrm{Fe}(\mathrm{III})$ chelate reductase to reduce $\mathrm{Fe}$ (III) chelates at root surface (strategy I) as well as an enhancement of phytosiderophore secretion to the rhizosphere, parallel to an induction of an Fe(III)-phytosiderophore complex transport system (strategy II) [2]. Salinity also presents several challenges to plant growth, including the decrease of the osmotic potential of the growing medium, a specific ion toxicity [3], and nutrient deficiencies and disorders [4].

Iron limitation and high-salinity stress have thus far been regarded as separate growth-limiting factors. Yet, the interaction effect of both stresses is little known. However, in sodic soils where $\mathrm{pH}$ and $\mathrm{Na}^{+}$concentration is high, the solubility of micronutrients is low $[5,6]$. According to Gupta et al. [7], in alkaline soils, the $\mathrm{pH}$ usually increases with an increase in salinity due to the presence of sodium-bicarbonate carbonates. Thus, plants growing in such soils encounter both $\mathrm{Na}^{+}$osmotic and toxicity effects and micronutrient deficiency. Besides, Jumberi et al. [5] found that the relative uptake of iron by barley and rye decreased with increasing soil sodicity. This result allows the suggestion of several hypotheses. It is thus possible that in the sodic soil, which has a high $\mathrm{pH}$ and $\mathrm{Na}^{+}$concentration, (i) the availability of iron is reduced either by the alkaline $\mathrm{pH}$ or by the formation of insoluble iron-phosphate complexes, (ii) the synthesis pathway of the iron chelators and uptake systems for iron was partially inhibited at high salinity, (iii) the effective complexation of iron by chelators could be negatively affected by the high ionic strength of the growth medium.

As far as we know that salinity stress inhibits the inducible mechanism of iron acquisition in some glycophytes. In fact, recently, it was found that salt had a depressive 
effect on root acidification in Medicago ciliaris plants [8] and on phytosiderophore release in barley [9]. Interestingly, recent studies demonstrated that expression of some proteins involved in iron uptake was significantly declined under salinity stress in barley salt-sensitive cv but highly induced in barley salt-tolerant cv [10]. Furthermore, it was previously demonstrated a high-salinity induction of genes encoding the synthesis pathway of chelators and uptake systems for iron in Bacillus subtilis [11] as consequence of iron limitation.

In the present study, our objective was to investigate a comparative study between two graminaceous species differing by their salinity tolerance: $H$. vulgare (cultivated barley) a glycophyte species and $H$. maritimum (wild barley) a halophyte native of salted soils where it significantly contributes to the annual biomass production in such ecosystems [12], in order to know the impact of salinity on iron uptake and on the inducible mechanism of its acquisition and to examine if the eventual impact is dependent on the tolerance of plant to salinity.

\section{Materials and Methods}

2.1. Plant Material and Growth Conditions. Seeds of H. maritimum, collected from Soliman Sebkha $(30 \mathrm{~km}$ south of Tunis, semiarid stage) and $H$. vulgare were germinated in quartz sand moistened with saturated $\mathrm{CaSO}_{4}$ solution in darkness for 6 days. Afterwards, seedlings were transferred to $2.8 \mathrm{~L}$ pot containing the following nutrient solution with $(+\mathrm{Fe})$ or without (-Fe) supply of $10^{-4} \mathrm{mMFe}(\mathrm{III})-E D T A: 0.7 \mathrm{mM} \mathrm{K}_{2} \mathrm{SO}_{4}$, $0.1 \mathrm{mM} \mathrm{KCl}, 2 \mathrm{mM} \mathrm{NH}_{4} \mathrm{NO}_{3}, 2 \mathrm{mM} \mathrm{CaCl}_{2}, 0.5 \mathrm{mM} \mathrm{MgSO}_{4}$, $0.1 \mathrm{mM} \mathrm{KH}_{2} \mathrm{PO}_{4}, \quad 10 \mu \mathrm{M} \mathrm{H}_{3} \mathrm{BO}_{3}, \quad 0.5 \mu \mathrm{M} \mathrm{MnSO}_{4}, \quad 0.5 \mu \mathrm{M}$ $\mathrm{ZnSO}_{4}, 0.2 \mu \mathrm{M} \mathrm{CuSO}_{4}$, and $0.01 \mu \mathrm{M}\left(\mathrm{NH}_{4}\right)_{6} \mathrm{Mo}_{7} \mathrm{O}_{24}$. During culture period, nutrient solution was changed every 3 days and continuously aerated. Nine days after appearance of iron chlorosis, salinity treatment was applied by supplying $\mathrm{NaCl}$ at four concentration levels $(0,100,200$, and $300 \mathrm{mM})$ for 60 hours. Experiments were conducted in a climate chamber with 55\% humidity, a light intensity of $200 \mu \mathrm{mol}$ photons $\mathrm{m}^{-2} \mathrm{~s}^{-1}$ and $\mathrm{a} 16 / 8\left(24 / 20^{\circ} \mathrm{C}\right)$ day-night regime.

Determination of Chlorophyll Content. Total chlorophyll contents in the youngest expanded leaves were determined following the method of Arnon [13].

Total chlorophyll $(\mathrm{mg} / \mathrm{L})=20.2 * A_{645}+8.02 * A_{663}$.

2.2. Leaf Gas Exchange Characteristics. Leaf gas exchange parameters, such as, net $\mathrm{CO}_{2}$ assimilation $(A)$, stomatal conductance $\left(g_{\mathrm{s}}\right)$, and transpiration rate $(E)$ were measured in both species grown in a greenhouse on iron sufficient or deficient medium then exposed to three different salt treatments $(0,100$, and $200 \mathrm{mM} \mathrm{NaCl})$ during $60 \mathrm{~h}$ using a portable photosynthesis system (LC pro+). Measurements were taken from the midlamina portion of the abaxial surface of the youngest fully expanded leaf at the day of harvesting.
Measurement was made earlier from 10.30 to 12.00 a.m with the following conditions: leaf surface area $5.8 \mathrm{~cm}^{2}$, ambient $\mathrm{CO}_{2}$ concentration $\left(C_{\text {ref }}\right) 377.5 \mathrm{mmol} \mathrm{mol}^{-1}$, temperature of the leaf chamber varied from 28.8 to $33.3^{\circ} \mathrm{C}$, ambient pressure $(P) 1022 \mathrm{mBar}$ PPFD (Qleaf) at the leaf surface was the maximum up to $650 \mu \mathrm{mol} / \mathrm{m}^{2}$. Relative intercellular $\mathrm{CO}_{2}$ concentration $\left(C_{i} / C_{a}\right)$ was calculated as: $C_{i} / C_{a}=$ intercellular $\mathrm{CO}_{2}$ concentration/ambient $\mathrm{CO}_{2}$ concentration.

2.3. Collection of Root Exudates. Since PS release in cereal plant species follows a diurnal rhythm [14] the collection of root exudates was started $2 \mathrm{~h}$ after the onset of the light period. For the preparation of plants for root exudate collection, three replicates of 10 intact plants from each treatment were removed from the nutrient solution and their root system was washed in deionized water for $30 \mathrm{~min}$ before the start of the collection. For the collection itself, the root system was submerged into $500 \mathrm{~mL}$ deionized water for $4 \mathrm{~h}$ with continuous aeration. Thereafter, $10 \mathrm{mg} / \mathrm{L}$ Micropur (Roth, Karlsruhe, Germany) was added to prevent microbial degradation during further preparation of the root exudates. The solution containing the exudates, was filtered (Blue ribbon No 5893, Schleicher and Schüll Dassel, Germany) and subsequently vacuum concentrated at $50^{\circ} \mathrm{C}$ to a volume of about $20 \mathrm{~mL}$. The concentrated solutions were stored at $-20^{\circ} \mathrm{C}$ for later use.

2.4. Phytosiderophore Quantification. Phytosiderophores (PS) were indirectly determined by calculating the amount of FeIII mobilized from a saturated solution of $\mathrm{Fe}(\mathrm{OH})_{3}$ with a modified method of Takagi [15]. An aliquot of $2 \mathrm{~mL}$ of $1 \mathrm{mMFe}(\mathrm{OH})_{3}$ and $100 \mu \mathrm{L}$ of concentrated root exudates was added to a final volume of $10 \mathrm{~mL}$. The resulting mixture was shaken for $1 \mathrm{~h}$ at room temperature and then filtrated (Blue ribbon No 5893, Schleicher and Schüll, Dassel, Germany). Mobilized iron was determined by atomic absorption spectrometry and phytosiderophore release concentrations were calculated as Fe equivalents.

2.5. Tissue Iron and Sodium Analysis. Directly after root exudates collection, roots were carefully washed with solution of EDTA $(10 \mathrm{mM})$ for $10 \mathrm{~min}$ under contentious aeration in order to remove the apoplasmic iron then rinsed with distilled water. Thereafter, roots and shoots were separated and weighted for determination of biomass production and dried at $60^{\circ} \mathrm{C}$. Samples were ground with an agate grinder for nutrient extraction by digestion with nitric/ $\mathrm{H}_{2} \mathrm{O}_{2}(4: 3, \mathrm{v} / \mathrm{v})$. Samples were analyzed for Fe on a Perkin Elmer Analyst 100 Atomic Absorption Spectrophotometer. $\mathrm{Na}^{+}$was determined in the same extract using flame spectrometry.

2.6. Fe Absorption Efficiency Calculation. Fe absorption efficiency (FeAE) was determined as the ratio of total iron quantity $(\mu \mathrm{mol})$ accumulated in each plant during the experimental period to its root dry weight $(\mathrm{g})$.

2.7. Statistical Analysis. All data were subjected to one-way ANOVA test, and means were compared using the SPSS and 
TABLE 1: Interrelated photosynthetic parameters of total chlorophyll (TChl), stomatal conductance $\left(g_{s}\right)$, transpiration rate $(E)$, $\mathrm{CO}_{2}$ assimilation rate $(A)$, and relative intercellular $\mathrm{CO}_{2}$ concentration $\left(C_{i} / C_{a}\right.$, given as intercellular $\mathrm{CO}_{2}$ concentration/ambient $\mathrm{CO}_{2}$ concentration) in $H$. maritimum and $H$. vulgare plants hydroponically grown under iron supply $(+\mathrm{Fe})$ or iron starvation $(-\mathrm{Fe})$ at different salt levels $(0,100,200 \mathrm{mM})$ over $60 \mathrm{~h}$. Means of five replicates \pm SE. For each line, means followed by the same letters are not significantly different according to Duncan's test at $P \leq 0.05$.

\begin{tabular}{|c|c|c|c|c|c|c|c|}
\hline \multirow{2}{*}{$\mathrm{NaCl}(\mathrm{mM})$} & & \multicolumn{3}{|c|}{ H. maritimum } & \multicolumn{3}{|c|}{ H. vulgare } \\
\hline & & 0 & 100 & 200 & 0 & 100 & 200 \\
\hline \multirow{2}{*}{ TChl (mg/gFW) } & $+\mathrm{Fe}$ & $2.63 \pm 0.05^{\mathrm{b}}$ & $1.99 \pm 0.22^{\mathrm{ab}}$ & $1.74 \pm 0.50^{\mathrm{a}}$ & $2.69 \pm 0.18^{\mathrm{a}}$ & $2.32 \pm 0.31^{\mathrm{a}}$ & $2.30 \pm 0.19^{\mathrm{a}}$ \\
\hline & $-\mathrm{Fe}$ & $0.79 \pm 0.51^{\mathrm{a}}$ & $0.88 \pm 0.41^{\mathrm{a}}$ & $1.00 \pm 0.71^{\mathrm{a}}$ & $0.26 \pm 0.04^{\mathrm{a}}$ & $0.29 \pm 0.10^{\mathrm{b}}$ & $0.29 \pm 0.06^{\mathrm{b}}$ \\
\hline \multirow{2}{*}{$E\left(\mathrm{mmol} \mathrm{m}^{-2} \mathrm{~s}^{-1}\right)$} & $+\mathrm{Fe}$ & $2.76 \pm 2.10^{\mathrm{a}}$ & $2.77 \pm 0.13^{\mathrm{a}}$ & $2.32 \pm 0.38^{\mathrm{a}}$ & $4.16 \pm 0.60^{c}$ & $3.31 \pm 0.50^{\mathrm{b}}$ & $1.91 \pm 0.20^{\mathrm{a}}$ \\
\hline & $-\mathrm{Fe}$ & $4.12 \pm 1.36^{\mathrm{b}}$ & $3.06 \pm 0.42^{\mathrm{ab}}$ & $2.13 \pm 0.10^{\mathrm{a}}$ & $4.50 \pm 0.65^{c}$ & $1.74 \pm 0.54^{\mathrm{b}}$ & $1.33 \pm 0.22^{\mathrm{a}}$ \\
\hline \multirow{2}{*}{$g_{s}\left(\mathrm{~mol} \mathrm{~m}^{-2} \mathrm{~s}^{-1}\right)$} & $+\mathrm{Fe}$ & $0.74 \pm 0.36^{\mathrm{b}}$ & $0.48 \pm 0.05^{\mathrm{ab}}$ & $0.34 \pm 0.01^{\mathrm{a}}$ & $0.33 \pm 0.09^{c}$ & $0.15 \pm 0.02^{\mathrm{b}}$ & $0.07 \pm 0.01^{\mathrm{a}}$ \\
\hline & $-\mathrm{Fe}$ & $0.11 \pm 0.05^{\mathrm{a}}$ & $0.47 \pm 0.10^{\mathrm{c}}$ & $0.29 \pm 0.10^{\mathrm{b}}$ & $0.19 \pm 0.05^{c}$ & $0.05 \pm 0.02^{\mathrm{b}}$ & $0.04 \pm 0.01^{\mathrm{a}}$ \\
\hline \multirow{2}{*}{$A\left(\mu \mathrm{mol} \mathrm{m}{ }^{-2} \mathrm{~s}^{-1}\right)$} & $+\mathrm{Fe}$ & $19.1 \pm 3.06^{\mathrm{a}}$ & $18.2 \pm 1.97^{\mathrm{a}}$ & $15.8 \pm 2.12^{\mathrm{a}}$ & $16.0 \pm 1.50^{c}$ & $10.3 \pm 0.86^{\mathrm{b}}$ & $6.94 \pm 0.89^{a}$ \\
\hline & $-\mathrm{Fe}$ & $0.82 \pm 0.22^{\mathrm{a}}$ & $3.21 \pm 0.42^{c}$ & $2.27 \pm 0.12^{\mathrm{b}}$ & $1.78 \pm 0.90^{c}$ & $1.13 \pm 0.31^{\mathrm{b}}$ & $0.85 \pm 0.21^{\mathrm{a}}$ \\
\hline \multirow{2}{*}{$C_{i} / C_{a}$} & $+\mathrm{Fe}$ & $0.75 \pm 0.03^{\mathrm{a}}$ & $0.73 \pm 0.03^{\mathrm{a}}$ & $0.69 \pm 0.04^{\mathrm{a}}$ & $0.68 \pm 0.03^{c}$ & $0.58 \pm 0.03^{\mathrm{b}}$ & $0.46 \pm 0.03^{\mathrm{a}}$ \\
\hline & $-\mathrm{Fe}$ & $0.90 \pm 0.02^{\mathrm{ab}}$ & $0.94 \pm 0.01^{\mathrm{b}}$ & $0.89 \pm 0.09^{\mathrm{a}}$ & $0.93 \pm 0.05^{\mathrm{c}}$ & $0.80 \pm 0.05^{\mathrm{b}}$ & $0.65 \pm 0.04^{\mathrm{a}}$ \\
\hline
\end{tabular}

the means among treatments were compared with Duncan's test.

\section{Results}

3.1. Interrelated Photosynthetic Parameters. Effects of salinity, iron deficiency, and the interaction of both stresses on total chlorophyll contents, photosynthetic assimilation rate $(A)$, stomatal conductance $\left(g_{\mathrm{s}}\right)$, and transpiration rate $(E)$ of $H$. vulgare and $H$. maritimum leaves are shown in Table 1. After 12 days of iron deficiency, chlorophyll contents in the youngest leaves were drastically decreased. Thus, reduction in cultivated barley was more than $90 \%$ while in wild one was less than $70 \%$ comparatively to control plants. Addition of salt to the nutrient medium with Fe supply slightly decreased chlorophyll contents with increasing salt stress level, but the reduction was more significant in $H$. maritimum than in $H$. vulgare (Table 1). In Fe-deficient plants, salt application practically did not have any effect on chlorophyll concentrations in both species (Table 1). Under iron deficiency, transpiration rate $(E)$ was enhanced especially in $H$. maritimum (Table 1). Application of salt reduced the transpiration rate $(E)$ especially in cultivated barley whatever the availability of iron in the medium was, but the reduction was more significant in $H$. vulgare than in $H$. maritimum. Under iron sufficiency, stomatal conductance $\left(g_{\mathrm{s}}\right)$, and consequently the photosynthetic assimilation rate $(A)$, always declined with increasing salt concentration. However, the reduction was more dramatic in $H$. vulgare than in $H$. maritimum. The combination of both stresses ( $-\mathrm{Fe},+$ salt treatment) led to enhance the stomatal conductance $\left(g_{\mathrm{s}}\right)$, and consequently the photosynthetic assimilation rate $(A)$ in $H$. maritimum as compared to plants subjected to separate iron deficiency (-Fe treatment), unlike $H$. vulgare. Relative intercellular $\mathrm{CO}_{2}$ concentration generally increased under iron deficiency conditions in both species (Table 1). However, salt application led to decrease this parameter in
H. vulgare (salt sensitive species) whatever iron availability in the medium was, but, practically, did not have any effect on that of $H$. maritimum (salt tolerant species).

3.2. Shoot Water Status. A significant difference in water status between wild and cultivated barley was found when salt was added to the medium (Figure 1). In fact, shoot water content of $H$. vulgare was significantly reduced by salinity. Thus, the differences between 0, 100, 200, and $300 \mathrm{mM}$ were constantly significant and this manifestation was clear in iron deficient plants. However, in $H$. maritimum the differences between treatments, in most cases, remained marginal and they became statically significant only at the most severe salt treatment level $(300 \mathrm{mM} \mathrm{NaCl})$. Results showed that there was not a significant difference of shoot water contents between the both levels of iron treatment $(0$ and $100 \mu \mathrm{M} \mathrm{Fe})$ in H. maritimum.

3.3. Sodium Status in Plant Tissues. Whatever the iron availability in the medium was, salinity caused significant increases in both roots and shoots $\mathrm{Na}^{+}$contents in both species (Table 2). As a whole, shoots exhibited the higher $\mathrm{Na}^{+}$contents as compared to roots in both species. However, shoot cultivated barley had higher sodium concentrations in comparison with that of wild barley plants, whereas at the level of roots it was the opposite. Under iron deficiency conditions ( $-\mathrm{Fe},+$ salt treatment), tissue $\mathrm{Na}^{+}$concentrations in wild barley were, practically, maintained as compared to those of iron-fed plants ( $+\mathrm{Fe}$, +salt treatment). However, in cultivated barley, iron deficiency constraint led to a drastically increase of $\mathrm{Na}^{+}$concentrations especially in the level of shoots as compared to iron sufficient conditions. In fact, the increases were about 22 and $92 \%$ at the application of 200 and $300 \mathrm{mM} \mathrm{NaCl}$, respectively (Table 2). Nevertheless, $\mathrm{Na}^{+}$ distribution between organs was species dependent. Thus, shoots of cultivated barley plants exposed to $300 \mathrm{mM} \mathrm{NaCl}$ contained 97 and $93 \%$ of the total amount of sodium in 


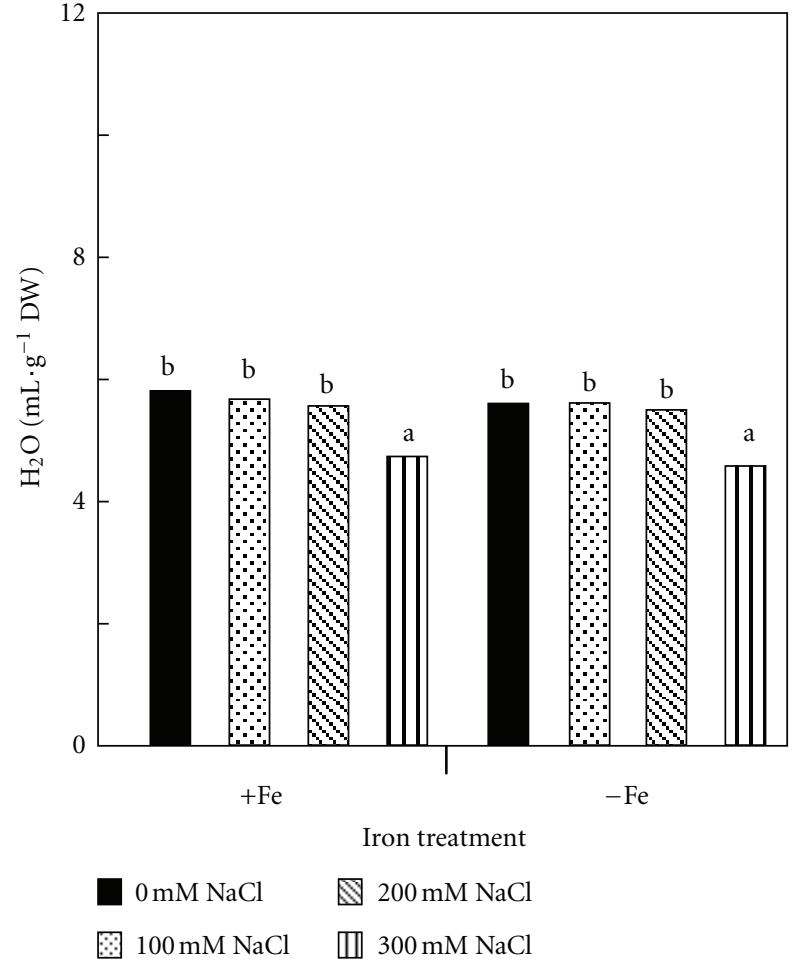

(a)

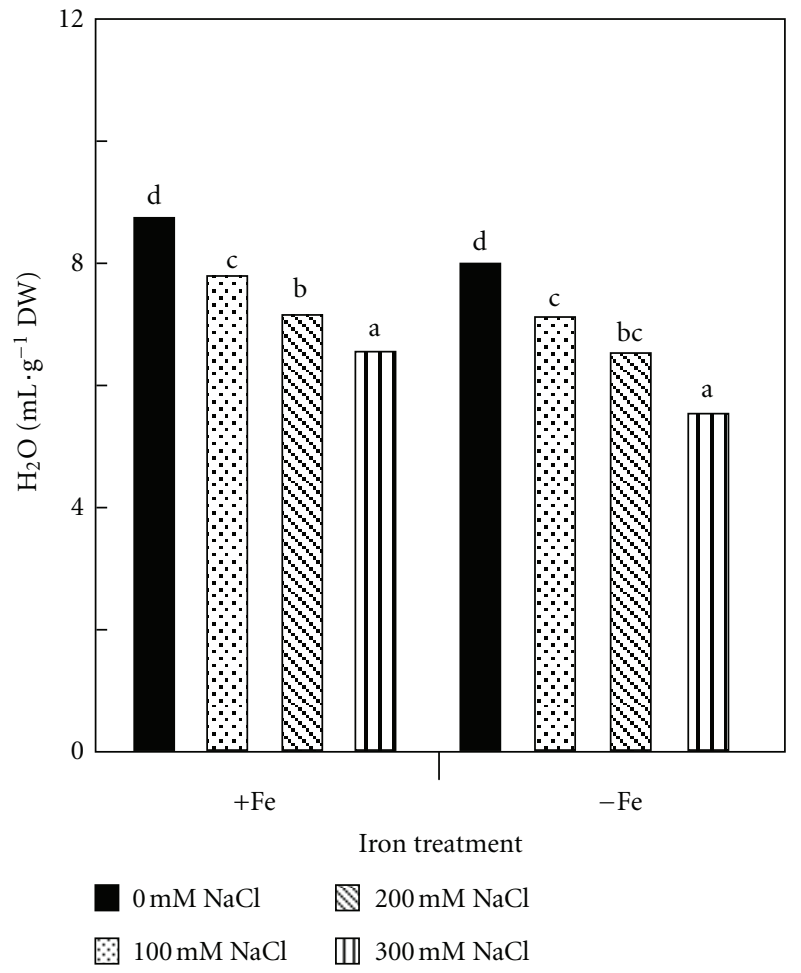

(b)

Figure 1: Effect of salinity $(0,100,200$, and $300 \mathrm{mM} \mathrm{NaCl})$ and iron availability $(+\mathrm{Fe}=100 \mu \mathrm{M}$ and $-\mathrm{Fe}=0 \mu \mathrm{M})$ in the culture solution on shoot water content of $H$. maritimum (a) and H. vulgare (b). Means of three replicates. Means followed by the same letters are not significantly different at $5 \%$ according to Duncan's test.

TABLE 2: $\mathrm{Na}^{+}$concentrations ( $\mathrm{mmol} \mathrm{Na}{ }^{+} \cdot \mathrm{g}^{-1} \mathrm{DW}$ ) in shoots and roots of $H$. maritimum and $H$. vulgare plants hydroponically grown under iron supply $(+\mathrm{Fe})$ or iron starvation $(-\mathrm{Fe})$ at different salt levels $(0,100,200,300 \mathrm{mM})$ over $60 \mathrm{~h}$. Means of three replicates. For each line, means followed by the same letters are not significantly different at $5 \%$ according to Duncan's test.

\begin{tabular}{|c|c|c|c|c|c|c|c|c|}
\hline \multirow[b]{2}{*}{$\mathrm{NaCl}(\mathrm{mM})$} & \multicolumn{4}{|c|}{ Shoots } & \multicolumn{4}{|c|}{ Roots } \\
\hline & 0 & 100 & 200 & 300 & 0 & 100 & 200 & 300 \\
\hline \multicolumn{9}{|c|}{ H. maritimum } \\
\hline \multicolumn{9}{|c|}{ Iron treatment } \\
\hline$+\mathrm{Fe}$ & $0.03^{\mathrm{a}}$ & $0.66^{\mathrm{b}}$ & $1.06^{\mathrm{c}}$ & $1.34^{\mathrm{d}}$ & $0.09^{\mathrm{a}}$ & $0.59^{\mathrm{b}}$ & $0.82^{\mathrm{c}}$ & $0.82^{\mathrm{c}}$ \\
\hline$-\mathrm{Fe}$ & $0.03^{\mathrm{a}}$ & $0.76^{\mathrm{b}}$ & $0.99^{\mathrm{c}}$ & $1.27^{\mathrm{d}}$ & $0.11^{\mathrm{a}}$ & $0.58^{\mathrm{b}}$ & $0.84^{\mathrm{c}}$ & $0.87^{\mathrm{c}}$ \\
\hline \multicolumn{9}{|c|}{ H. vulgare } \\
\hline \multicolumn{9}{|c|}{ Iron treatment } \\
\hline$+\mathrm{Fe}$ & $0.029^{\mathrm{a}}$ & $0.64^{\mathrm{b}}$ & $1.33^{\mathrm{c}}$ & $1.84^{\mathrm{d}}$ & $0.10^{\mathrm{a}}$ & $0.42^{\mathrm{b}}$ & $0.49^{\mathrm{b}}$ & $0.56^{\mathrm{c}}$ \\
\hline$-\mathrm{Fe}$ & $0.03^{\mathrm{a}}$ & $0.56^{\mathrm{b}}$ & $1.63^{\mathrm{c}}$ & $2.86^{\mathrm{d}}$ & $0.11^{\mathrm{a}}$ & $0.60^{c}$ & $0.67^{\mathrm{d}}$ & $0.53^{\mathrm{b}}$ \\
\hline
\end{tabular}

the plant, respectively, in iron deficient and sufficient plants. However, in wild one, the amount of $\mathrm{Na}^{+}$allocated to shoots did not exceed $75 \%$, either in iron deficient or iron sufficient plants (Table 3 ).

3.4. Iron Status in Plant Tissues. Our results indicated that salt stress generally provoked an iron limitation in both species (Table 4). It was incredibly clear that iron concentrations were constantly decreased with increasing salt treatment level. In fact, the decrease of iron concentrations in $H$. vulgare (+Fe, +salt treatment) was $35-48 \%$ and $18-$ $88 \%$, respectively, in shoots and roots as compared to control ones (+Fe treatment, -salt treatment). In H. maritimum, the reduction of root iron concentrations was about 56$81 \%$, while those of shoots were not affected. Besides, iron absorption efficiency (FeAE) was reduced in both species with increasing salt treatment level. Indeed, $300 \mathrm{mM} \mathrm{NaCl}$ caused a reduction of 65 and $72 \%$ in iron absorption efficiency, respectively, in $H$. maritimum and $H$. vulgare fed with $100 \mu \mathrm{M}$ Fe (Table 5).

3.5. Effect of Salt Stress on Phytosiderophore Exudation. Under iron deficiency, we obtained an induction of root exudation in both species. The amount of phytosiderophore (PS) 
TABLE 3: $\mathrm{Na}^{+}$allocation to shoots of $H$. maritimum and $H$. vulgare plants hydroponically grown under iron supply (+Fe) or iron starvation $(-\mathrm{Fe})$ at different salt levels $(0,100,200,300 \mathrm{mM})$ over $60 \mathrm{~h}$.

\begin{tabular}{|c|c|c|c|c|c|c|c|c|}
\hline \multirow[b]{2}{*}{$\mathrm{NaCl}(\mathrm{mM})$} & \multicolumn{4}{|c|}{ H. maritimum } & \multicolumn{4}{|c|}{ H. vulgare } \\
\hline & 0 & 100 & 200 & 300 & 0 & 100 & 200 & 300 \\
\hline & & & & & & & & \\
\hline \multicolumn{9}{|c|}{ Iron treatment } \\
\hline$+\mathrm{Fe}$ & 40 & 69 & 73 & 75 & 62 & 89 & 93 & 93 \\
\hline$-\mathrm{Fe}$ & 36 & 73 & 71 & 75 & 49 & 78 & 91 & 97 \\
\hline
\end{tabular}

TABLE 4: Fe concentrations ( $\mu \mathrm{mol} \mathrm{Fe} \cdot \mathrm{g}^{-1} \mathrm{DW}$ ) in shoots and roots of $H$. maritimum and $H$. vulgare plants hydroponically grown under iron supply $(+\mathrm{Fe})$ or iron starvation $(-\mathrm{Fe})$ at different salt levels $(0,100,200,300 \mathrm{mM})$ over $60 \mathrm{~h}$. Means of three replicates. For each line, means followed by the same letters are not significantly different at $5 \%$ according to Duncan's test.

\begin{tabular}{|c|c|c|c|c|c|c|c|c|}
\hline \multirow[b]{2}{*}{$\mathrm{NaCl}(\mathrm{mM})$} & \multicolumn{4}{|c|}{ Shoots } & \multicolumn{4}{|c|}{ Roots } \\
\hline & 0 & 100 & 200 & 300 & 0 & 100 & 200 & 300 \\
\hline \multicolumn{9}{|c|}{ H. maritimum } \\
\hline \multicolumn{9}{|c|}{ Iron treatment } \\
\hline$+\mathrm{Fe}$ & $1.97^{\mathrm{a}}$ & $2.08^{\mathrm{a}}$ & $2.07^{\mathrm{a}}$ & $2.07^{\mathrm{a}}$ & $16.7^{\mathrm{a}}$ & $7.37^{\mathrm{b}}$ & $6.07^{\mathrm{c}}$ & $3.11^{\mathrm{d}}$ \\
\hline$-\mathrm{Fe}$ & $1.99^{\mathrm{b}}$ & $2.39^{\mathrm{a}}$ & $1.87^{\mathrm{b}}$ & $1.23^{\mathrm{c}}$ & $3.12^{\mathrm{a}}$ & $2.09^{\mathrm{b}}$ & $1.65^{\mathrm{c}}$ & $2.00^{\mathrm{b}}$ \\
\hline \multicolumn{9}{|c|}{ H. vulgare } \\
\hline \multicolumn{9}{|c|}{ Iron treatment } \\
\hline$+\mathrm{Fe}$ & $2.55^{\mathrm{a}}$ & $1.53^{\mathrm{b}}$ & $1.28^{\mathrm{c}}$ & $1.19^{\mathrm{cd}}$ & $9.75^{\mathrm{a}}$ & $7.99^{\mathrm{b}}$ & $7.88^{\mathrm{b}}$ & $1.14^{\mathrm{c}}$ \\
\hline$-\mathrm{Fe}$ & $0.86^{\mathrm{a}}$ & $0.79^{\mathrm{ab}}$ & $0.65^{\mathrm{c}}$ & $0.33^{\mathrm{d}}$ & $1.20^{\mathrm{a}}$ & $1.06^{\mathrm{a}}$ & $1.51^{\mathrm{a}}$ & $1.66^{\mathrm{a}}$ \\
\hline
\end{tabular}

Table 5: Salinity effect $(0,100,200$, and $300 \mathrm{mM} \mathrm{NaCl})$ on $\mathrm{Fe}$ absorption efficiency (FeAE) in $H$. maritimum and $H$. vulgare grown on nutrient solution containing $100 \mu \mathrm{M}$ Fe. Means of three replicates. For each line, means followed by the same letters are not significantly different at $5 \%$ according to Duncan's test.

\begin{tabular}{lcccc}
\hline & \multicolumn{4}{c}{ FeAE $(\mu \mathrm{mol}$ Fe/g root DW $)$} \\
$\mathrm{NaCl}(\mathrm{mM})$ & 0 & 100 & 200 & 300 \\
\hline H. maritimum & $26^{\mathrm{d}}$ & $14.5^{\mathrm{c}}$ & $12.8^{\mathrm{b}}$ & $9.08^{\mathrm{a}}$ \\
H. vulgare & $17.7^{\mathrm{d}}$ & $11.79^{\mathrm{c}}$ & $10.2^{\mathrm{b}}$ & $4.88^{\mathrm{a}}$ \\
\hline
\end{tabular}

secreted by iron deficient plants ( - Fe treatment) was at least 10 times higher than those released by iron sufficient plants (+Fe treatment) (Figure 2). Thus, the PS exudation amount of iron deficient plants ( - Fe treatment) reached, at least, $250 \mu \mathrm{mol} / \mathrm{g}$ root FW $4 \mathrm{~h}^{-1}$, but that of iron sufficient ones did not exceeded $32 \mu \mathrm{mol} / \mathrm{g}$ root FW $4 \mathrm{~h}$. H. vulgare had the highest PS exudation amount as compared to H. maritimum. Salt application had an effect on PS exudation, which clearly depended on salt-concentration-applied species and iron availability in the medium (Figure 2). In fact, the application of $100 \mathrm{mM} \mathrm{NaCl}$ to iron deficient plants $(-\mathrm{Fe}$, $+100 \mathrm{mM} \mathrm{NaCl}$ treatment) enhanced PS root exudation in both species without exception as compared to nonsaltstressed plants $(-\mathrm{Fe}$ treatment, $+0 \mathrm{mMNaCl}$ treatment). However, up to $100 \mathrm{mM} \mathrm{NaCl}$, the responses of two species became slightly complicated. Thus, at $200 \mathrm{mM} \mathrm{NaCl}$, wild barley iron-deficient plants ( $-\mathrm{Fe},+200 \mathrm{mM} \mathrm{NaCl}$ treatment) still released practically the same amount of PS which detected at $-\mathrm{Fe}$ treatment and showed a PS inhibition only at $300 \mathrm{mM} \mathrm{NaCl}$, while that of cultivated ones $(-\mathrm{Fe}$, +salt treatment) it started to be drastically decreased from $200 \mathrm{mM} \mathrm{NaCl}$. In the presence of $100 \mu \mathrm{M} \mathrm{Fe}$, stimulation of PS release under salt stress occurred in both species despite the fact that the growth medium contained enough iron $(100 \mu \mathrm{M})$ to repress PS exudation. Increasing the salinity of the growth medium that contained $100 \mu \mathrm{M} \mathrm{Fe}(+\mathrm{Fe}$, +salt treatment) triggered an increase in PS levels, resulting in a linear relationship between the salt concentration and the amount of PS exuded (Figure 3). It was only at the highest salinity level $(300 \mathrm{mM} \mathrm{NaCl})$ that the two species exhibited different variations in PS exudations; a sharp decline was observed in $H$. vulgare ( $+\mathrm{Fe}, 300 \mathrm{mM} \mathrm{NaCl}$ treatment) restoring the value of control plants $(+\mathrm{Fe}$ treatment) versus a strong improvement in $\mathrm{H}$. maritimum $(+\mathrm{Fe}, 300 \mathrm{mM} \mathrm{NaCl}$ treatment).

\section{Discussion}

It is clear that as salinity increase, iron uptake was constantly decreased in both species. Besides, iron absorption efficiency (FeAE) was reduced in both species with increasing salt level treatment. Indeed, $300 \mathrm{mM} \mathrm{NaCl}$ caused a reduction of 65 and $72 \%$ in iron absorption efficiency, respectively, in $H$. maritimum and $H$. vulgare fed with $100 \mu \mathrm{M}$ Fe (Table 5). In agreement with our result, Bacillus subtilis cells [11], H. vulgare L. [9], Matricaria chamomilla L. [16], and Medicago ciliaris L. [8] grew at salinity-experienced iron limitation.

The magnitude of salt effect on different organ iron contents was genetically dependent. Thus, iron contents were constantly reduced in roots of both species with increasing salinity level, while that of shoots were drastically reduced 


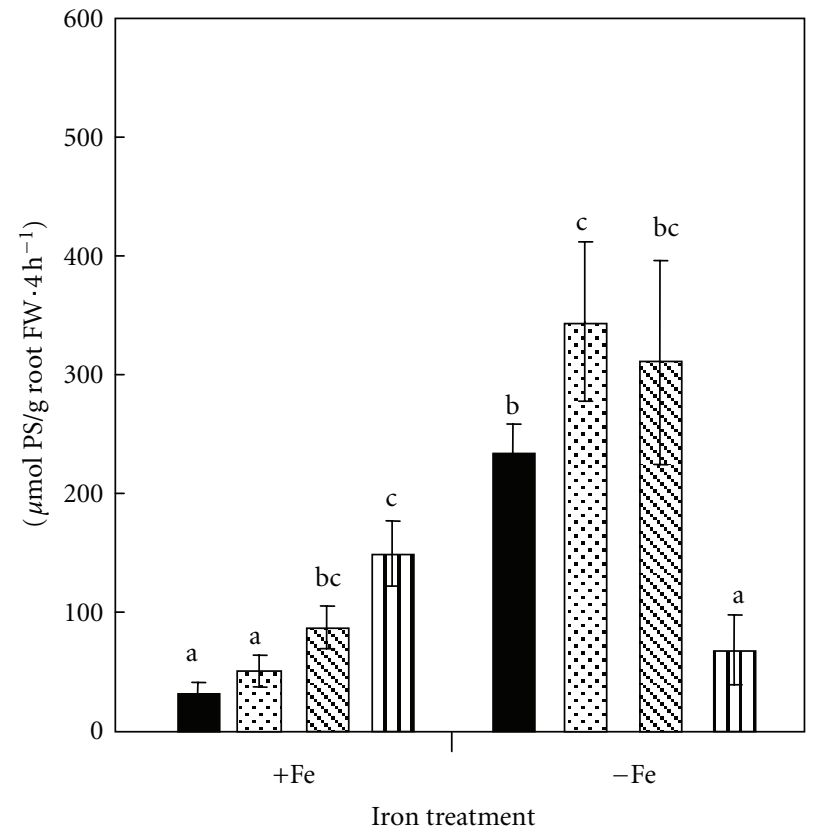

$0 \mathrm{mM} \mathrm{NaCl} 200 \mathrm{mM} \mathrm{NaCl}$

. $100 \mathrm{mM} \mathrm{NaCl}$ 吕 $300 \mathrm{mM} \mathrm{NaCl}$

(a)

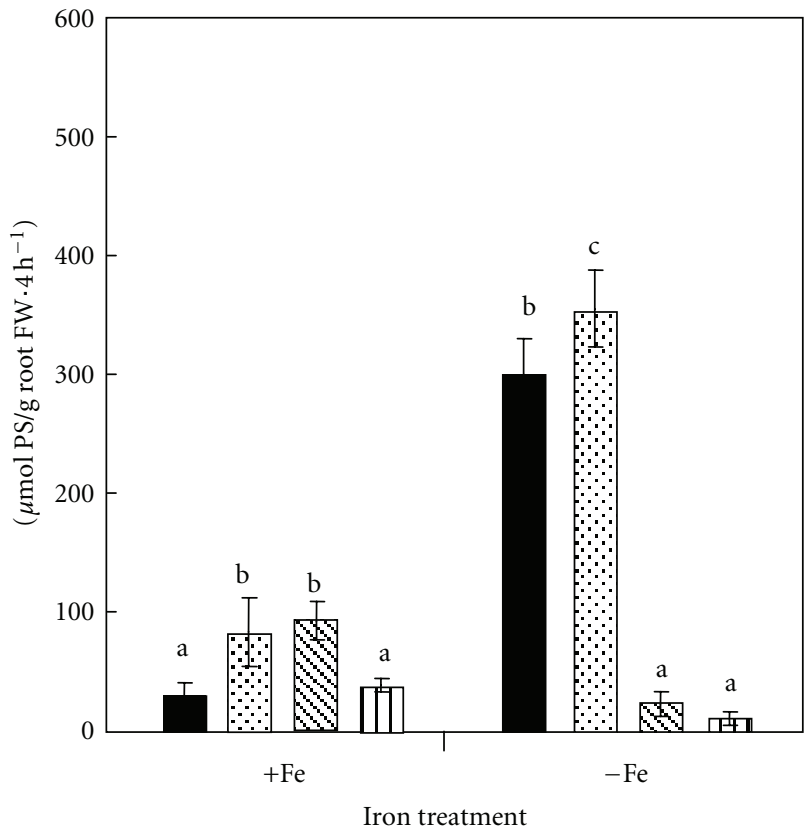

$0 \mathrm{mM} \mathrm{NaCl} \quad 200 \mathrm{mM} \mathrm{NaCl}$

$100 \mathrm{mM} \mathrm{NaCl}$ 四 $300 \mathrm{mM} \mathrm{NaCl}$

(b)

Figure 2: Effect of salinity $(0,100,200$, and $300 \mathrm{mM} \mathrm{NaCl})$ and iron availability $(+\mathrm{Fe}=100 \mu \mathrm{M}$ and $-\mathrm{Fe}=0 \mu \mathrm{M})$ in the culture solution on phytosiderophore (PS) release rates of H. maritimum (a) and H. vulgare (b). Means of three replicates \pm SE. Means followed by the same letters are not significantly different at $5 \%$ according to Duncan's test.

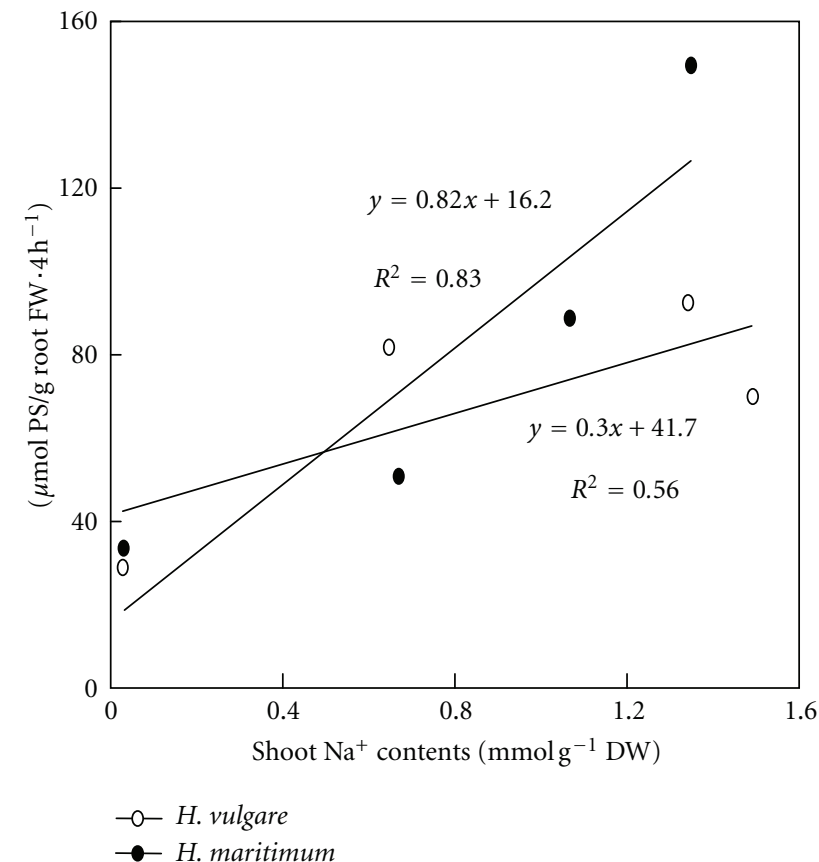

(a)

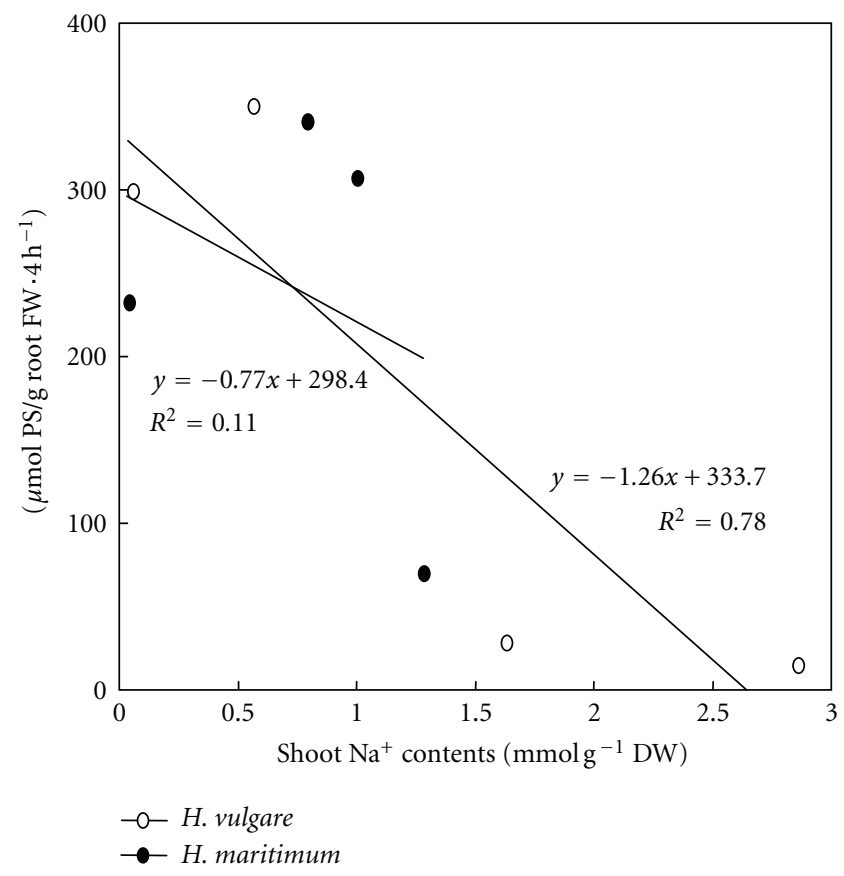

(b)

Figure 3: Phytosiderophore (PS) exudation rates ( $\mathrm{mmol} / \mathrm{g}$ root $\mathrm{FW} \cdot 4 \mathrm{~h}^{-1}$ ) as a function of shoot $\mathrm{Na}^{+}$concentration (mmol/g DW) in the presence (a) or the absence of Fe (b). White symbols stand for H. vulgare while black symbols stand for H. maritimum. 
in $H$. vulgare andremained invariable $(+\mathrm{Fe},+$ salt treatment $)$ or slightly reduced $(-\mathrm{Fe}$, + salt treatment) in $\mathrm{H}$. maritimum as compared to control $(+\mathrm{Fe}$ or $-\mathrm{Fe}$ treatment, resp.). This is consistent with literature reports. In fact, several studies proved that salinity reduces Fe content in shoots of barley, [9], medicago [8], wheat, and faba bean [17]. Nevertheless, high Fe contents were found in shoots of tomato, soybean, squash [18], and rye [5] plants grown on saline soil. Grattan and Grieve [19] attributed these contrasting results to plant and tissue type, salinity level and composition, iron concentration in the medium, growing conditions, and the duration of treatment.

Iron limitation resulting either from direct iron deficiency or salt stress (inducible iron deficiency) was concomitant with an induction of phytosiderophore (PS) release (Figure 2). Such induction was significantly related to the genotype and the salt stress level. In fact, as it was previously proved that under iron deficiency, $H$. vulgare released an amount of PS higher than H. maritimum [20]. The correlation between shoot $\mathrm{Na}^{+}$concentrations and the amount of PS released from root system was investigated (Figure 3). As a result, in plants fed with iron $(+\mathrm{Fe}$, + salt treatment), a positive correlation was found between shoot $\mathrm{Na}^{+}$concentrations and PS exudation in both species but was more significant in wild barley than in cultivated one $\left(R^{2}=\right.$ 0,831 and $R^{2}=0,565$, resp.) (Figure $3(\mathrm{a})$ ). However, in iron deficient plants ( $-\mathrm{Fe},+$ salt treatment), a strong negative correlation was found between shoot $\mathrm{Na}^{+}$concentrations and PS exudation in cultivated barley $\left(R^{2}=0,780\right)$, while no relation was observed in wild one $\left(R^{2}=0,113\right)$ (Figure $3(\mathrm{~b}))$. These findings allow speculating that $H$. maritimum was more efficient than $H$. vulgare to safeguard its inducible mechanism of iron acquisition under salt stress. Besides, studies proved an intra- and interspecific variability in the protection or stimulation of the synthesis pathway of iron chelators and iron uptake systems [10-21].

For each species there is a threshold of $\mathrm{Na}^{+}$concentration beyond which PS exudation capacity was inhibited either in presence or absence of iron in the medium. In H. vulgare, such threshold was 0.56 and $1.33 \mathrm{mmol} \mathrm{Na}^{+} \mathrm{g}^{-1}$ shoot DW under iron starvation and iron supply, respectively, while in $H$. maritimum it was $1.0 \mathrm{mmol} \mathrm{Na}^{+} \mathrm{g}^{-1}$ shoot DW under iron starvation and more than $1.34 \mathrm{mmol} \mathrm{Na}^{+} \mathrm{g}^{-1}$ shoot DW under iron supply. The thresholds of $\mathrm{Na}^{+}$concentration beyond which phytosiderophore release was reduced were higher in $H$. maritimum than in $H$. vulgare. Along with this finding, one can assume that wild barley was more efficient in the sequestration of $\mathrm{Na}^{+}$as compared to cultivated one. This could be justified by the slight reduction of shoot water contents in $H$. maritimum as compared to $H$. vulgare (Figure 1 ). Indeed, as it was mentioned in literature that the bad compartmentalization of salt ions $\left(\mathrm{Na}^{+}\right.$and $\left.\mathrm{Cl}^{-}\right)$increases the risk of tissues deshydratation [22]. Furthermore, at high salinity levels (200 and $300 \mathrm{mM}$ ), $H$. maritimum accumulated relatively lesser amount of $\mathrm{Na}^{+}$in shoots than did $H$. vulgare. Thus, it appears that the former was also more efficient than the latter in "controlling" the total amount of $\mathrm{Na}^{+}$reaching the leaves [23].
Our data clearly demonstrated that due to the osmotic effect, which was dramatic in cultivated barley as compared to wild one, interrelated photosynthetic parameters (transpiration rate, stomatal conductance, and assimilation rate) were significantly reduced in $H$. vulgare than in $H$. maritimum. Thus, controlling $\mathrm{Na}^{+}$transport to photosynthetic organs and its sequestration, which were critically appeared in wild barley, avoided the osmotic effect and its repercussion on photosynthetic activity, which might be indirectly involved in PS biosyntheses and secretion pathway [15-25]. In addition, we found that the maintaining of PS release under salt stress was closely related to plant iron status, which is the key of photosynthetic activities. In fact, the threshold of $\mathrm{Na}^{+}$shoot concentration which inhibited PS release was higher under iron supply than under iron starvation. Furthermore, the correlation between shoot $\mathrm{Na}^{+}$ concentration and PS release was positive in Fe-sufficient plants, whereas it was negative in Fe-deficient ones.

\section{Conclusion}

The controlling $\mathrm{Na}^{+}$transport to photosynthetic organs and its sequestration, which were more appeared in wild barley than in cultivated one, avoided the osmotic effect and its repercussion on Fe absorption efficiency and photosynthetic activity. Iron limitation resulting either from direct iron deficiency or salt stress (inducible iron deficiency) was concomitant with an induction of phytosiderophore release in both species. However, phytosiderophore exudation capacity was more maintained under salt stress in wild barley than in cultivated one.

\section{References}

[1] A. F. López-Millán, F. Morales, Y. Gogorcena, A. Abadía, and J. Abadía, "Metabolic responses in iron deficient tomato plants," Journal of Plant Physiology, vol. 166, no. 4, pp. 375-384, 2009.

[2] T. Kobayashi, N. K. Nishizawa, and S. Mori, "Molecular analysis of iron-deficient graminaceous plants," in Iron Nutrition in Plants and Rhizospheric Microorganisms, L. L. Barton and A. Abadia, Eds., pp. 395-436, Springer, Dordrecht, The Netherlands, 2006.

[3] Q. Luo, B. Yu, and Y. Liu, "Differential sensitivity to chloride and sodium ions in seedlings of Glycine max and G. soja under $\mathrm{NaCl}$ stress," Journal of Plant Physiology, vol. 162, no. 9, pp. 1003-1012, 2005.

[4] C. V. Santos, I. P. Falcão, G. C. Pinto, H. Oliveira, and J. Loureiro, "Nutrient responses and glutamate and proline metabolism in sunflower plants and calli under $\mathrm{Na}_{2} \mathrm{SO}_{4}$ stress," Journal of Plant Nutrition and Soil Science, vol. 165, no. 3, pp. 366-372, 2002.

[5] A. Jumberi, M. Yamada, S. Yamada, and H. Fujiyama, "Salt tolerance of grain crops in relation to ionic balance and ability to absorb microelements," Soil Science and Plant Nutrition, vol. 47, no. 4, pp. 657-664, 2001.

[6] A. L. Page, A. C. Chang, and D. C. Adriano, "Deficiencies and toxicities of trace elements," in Agricultural Salinity Assessment and Management, K. K. Tanji, Ed., ASCE Manuals and Reports on Engineering Practice No. 71, pp. 138-160, American Society of Civil Engineers, New York, NY, USA, 1990. 
[7] R. K. Gupta, R. R. Singh, and I. P. Abrol, "Influence of simultaneous changes in sodicity and $\mathrm{pH}$ on the hydraulic conductivity of an alkali soil under rice culture," Soil Science, vol. 147, pp. 28-33, 1989.

[8] M. Rabhi, Z. Barhoumi, R. Ksouri, C. Abdelly, and M. Gharsalli, "Interactive effects of salinity and iron deficiency in Medicago ciliaris," Comptes Rendus_Biologies, vol. 330, no. 11, pp. 779-788, 2007.

[9] S. Yousfi, M. Wissal, H. Mahmoudi, C. Abdelly, and M. Gharsalli, "Effect of salt on physiological responses of barley to iron deficiency," Plant Physiology and Biochemistry, vol. 45, no. 5, pp. 309-314, 2007.

[10] K. Witzel, A. Weidner, G. K. Surabhi, A. Börner, and H. P. Mock, "Salt stress-induced alterations in the root proteome of barley genotypes with contrasting response towards salinity," Journal of Experimental Botany, vol. 60, no. 12, pp. 3545-3557, 2009.

[11] T. Hoffmann, A. Schütz, M. Brosius, A. Völker, U. Völker, and E. Bremer, "High-salinity-induced iron limitation in Bacillus subtilis," Journal of Bacteriology, vol. 184, no. 3, pp. 718-727, 2002.

[12] C. Abdelly, M. Lachaal, C. Grignon, A. Soltani, and M. Hajji, "Episodic association of strict haplotypes and glycophytes in a saline, hydromorphic ecosystem in semi-arid zones," Agronomie, vol. 15, no. 9-10, pp. 557-568, 1995.

[13] D. I. Arnon, "Copper in enzymes in isolated chloroplasts polyphenoxidase in Beta vulgaris," Journal of Plant Physiology, vol. 24, pp. 1-15, 1949.

[14] F. Zhang, V. Römheld, and H. Marschner, "Release of zincmobilizing root exudates in different plant species as affected by zinc nutritional status," Journal of Plant Nutrition, vol. 14, pp. 675-686, 1991.

[15] S. Takagi, "The iron acquisition system in graminaceous plants and muggineic acid," in Nutriophysiology of Metal Related Compounds, Japanese Society of Soil Science and Plant Nutrition, Ed., pp. 6-51, Hakuyushia, Tokyo, Japan, 199.

[16] M. Heidarii and S. Saran, "Growth, biochemical components and ion content of Chamomile (Matricaria chamomilla L.) under salinity stress and iron deficiency," Journal of the Saudi Society of Agricultural Sciences, vol. 11, pp. 37-42, 2012.

[17] M. M. El Fouly, M. M. Zeinab, and A. S. Zeinab, "Micronutrient sprays as a tool to increase tolerance of faba bean and wheat plants to salinity," in Plant Nutrition and Food Security and Sustainability of Agro-Ecosystems, W. J. ;Schenk, M. K.;Bürkert, A. Horst, M. K. Schenk, A. Bürkert et al., Eds., pp. 422-423, Kluwer Academic, Dodrecht, The Netherlands, 2001.

[18] E. V. Maas, G. Ogata, and M. J. Garber, "Influence of salinity on Fe, Mn and Zn uptake by plants," Journal of Agronomy, vol. 64, pp. 793-795, 1972.

[19] S. R. Grattan and C. M. Grieve, "Salinity-mineral nutrient relations in horticultural crops," Scientia Horticulturae, vol. 78, no. 1-4, pp. 127-157, 1998.

[20] S. Yousfi, M. Rabhi, C. Abdelly, and M. Gharsalli, "Iron deficiency tolerance traits in wild (Hordeum maritimum) and cultivated barley (Hordeum vulgare)," Comptes RendusBiologies, vol. 332, no. 6, pp. 523-533, 2009.

[21] S. Roje, "S-Adenosyl-1-methionine: beyond the universal methyl group donor," Phytochemistry, vol. 67, no. 15, pp. 1686-1698, 2006.

[22] W. Fricke, G. Akhiyarova, W. Wei et al., "The short-term growth response to salt of the developing barley leaf," Journal of Experimental Botany, vol. 57, no. 5, pp. 1079-1095, 2006.
[23] A. J. Garthwaite, R. Von Bothmer, and T. D. Colmer, "Salt tolerance in wild Hordeum species is associated with restricted entry of $\mathrm{Na}^{+}$and $\mathrm{Cl}^{-}$into the shoots," Journal of Experimental Botany, vol. 56, no. 419, pp. 2365-2378, 2005.

[24] S. Kawai, T. Murakami, K. Kuwajima, T. Hirai, and M. Ishigami, "Rapid incorporation of ${ }^{14} \mathrm{C}$ of glucose into phytosiderophores in iron-deficient barley roots," Soil Science and Plant Nutrition, vol. 43, no. 1, pp. 75-84, 1997.

[25] N. von Wiren, S. Mori, H. Marschner, and V. Romheld, "Iron inefficiency in maize mutant ys 1 (Zea mays L. cv Yellow Stripe) is caused by a defect in uptake of iron phytosiderophores," Plant Physiology, vol. 106, no. 1, pp. 71-77, 1994. 


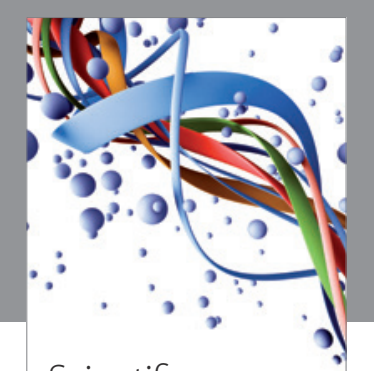

Scientifica
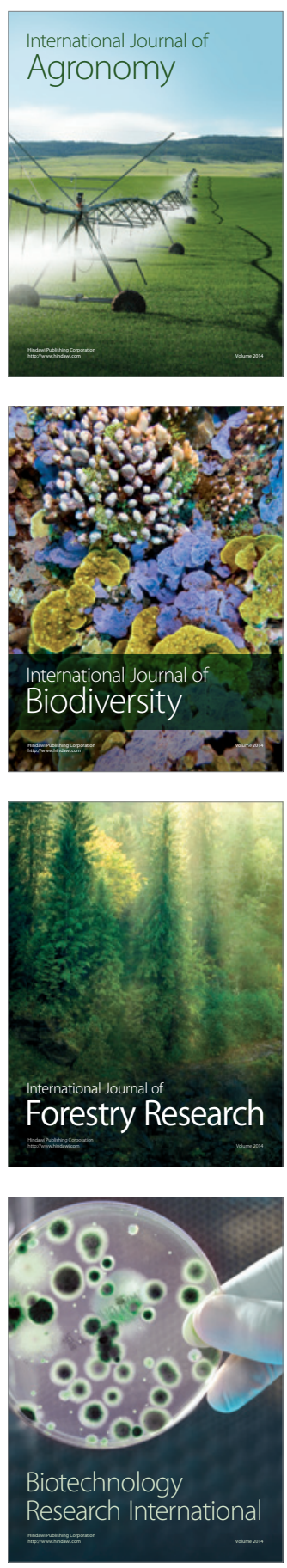
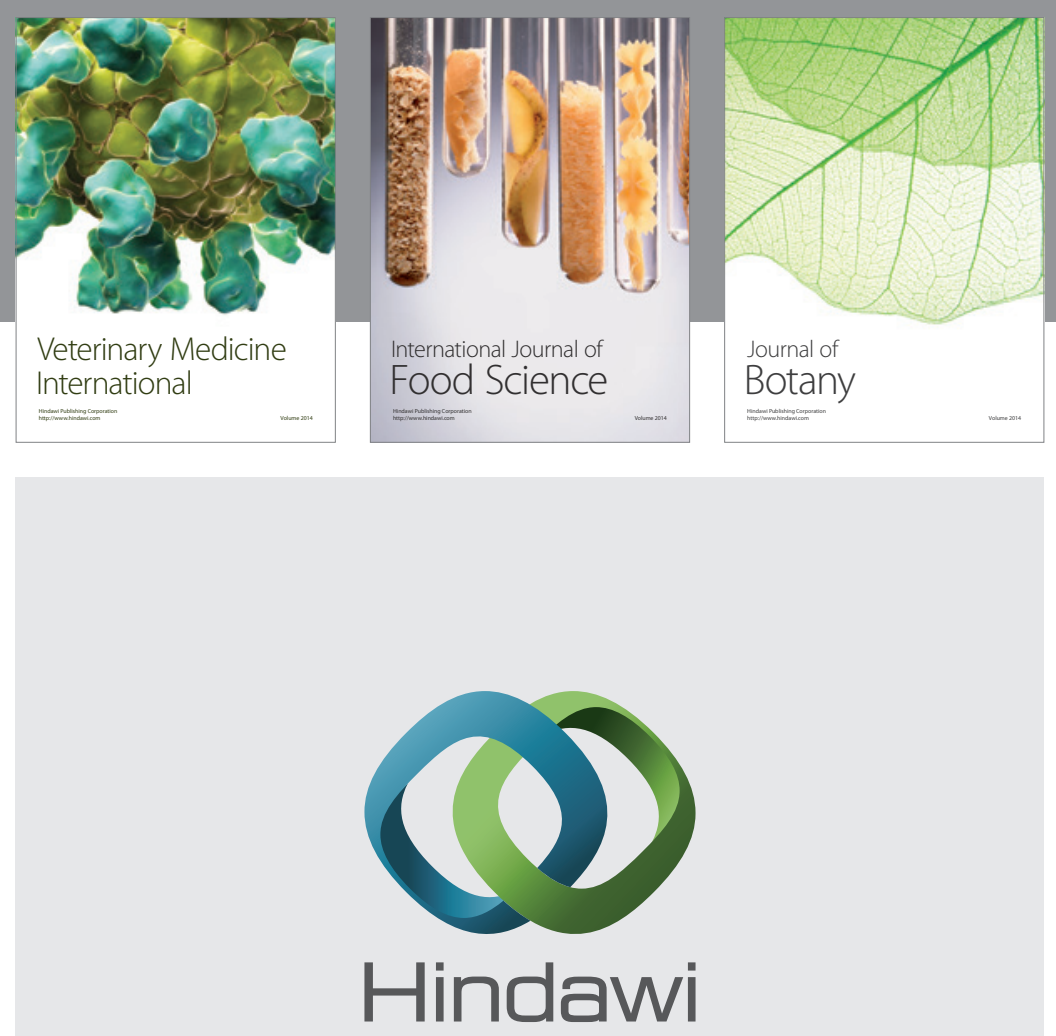

Submit your manuscripts at

http://www.hindawi.com
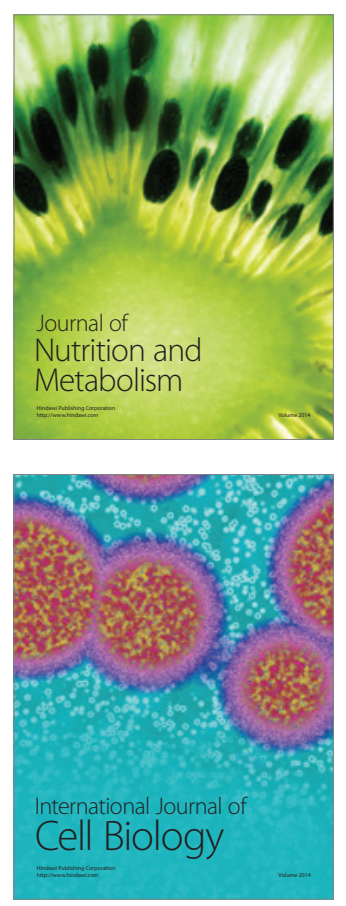
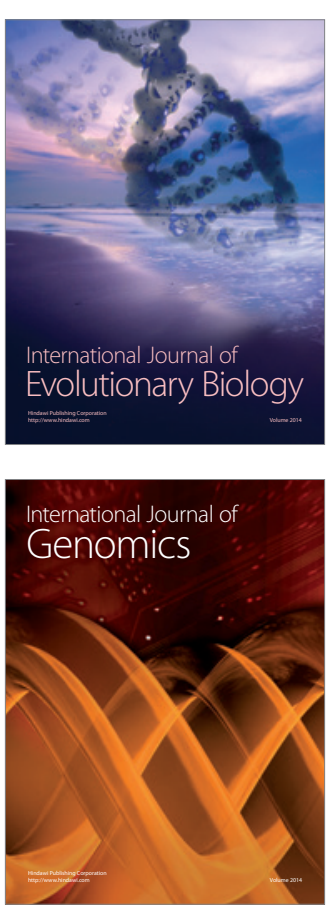
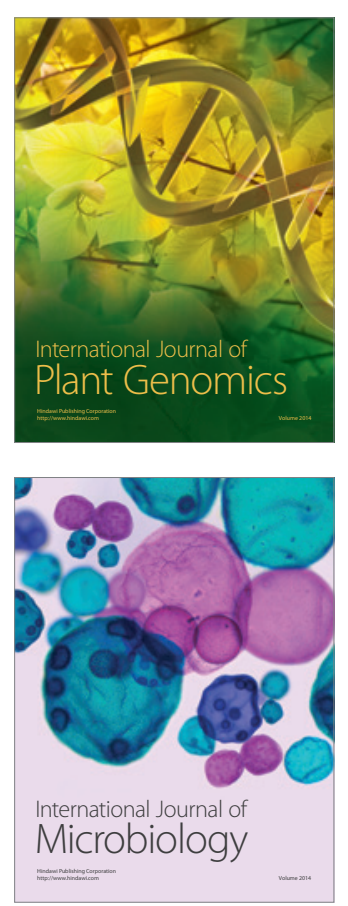

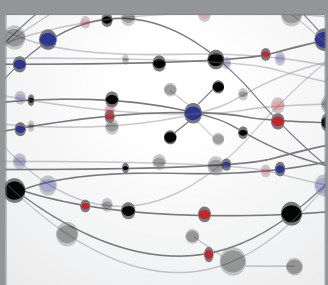

The Scientific World Journal
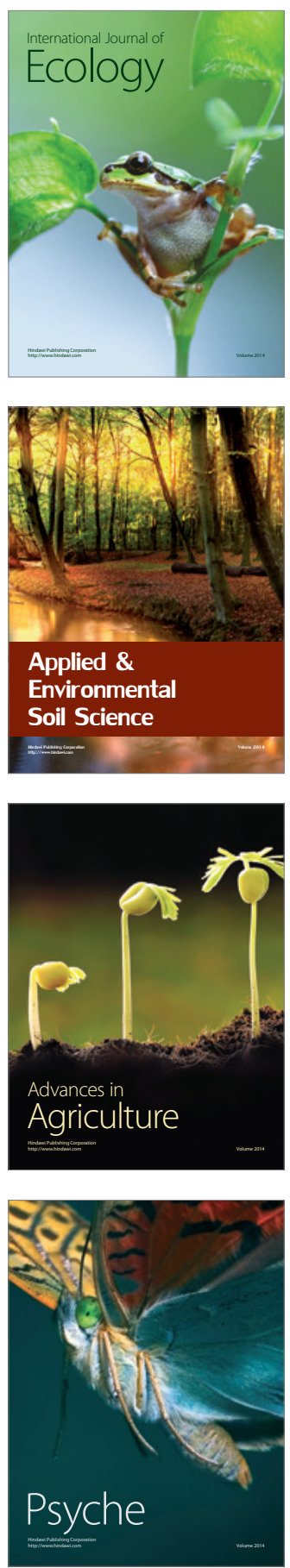